\title{
HISTORY, STATUS, AND FUTURE OF OYSTER CULTURE IN FRANCE
}

\author{
D. BUESTEL, ${ }^{1}$ M. ROPERT, ${ }^{2}$ J. PROU ${ }^{3}$ AND P. GOULLETQUER ${ }^{4}{ }^{\dagger}$ \\ Ifremer, ${ }^{1}$ Centre du Pacifique BP 7004, 98719 Taravao Tahiti; ${ }^{2}$ Station Ifremer, Avenue de Gaulle, 14520 \\ Port en Bessin, France; ${ }^{3}$ Station Ifremer, BP 133, 17390 La Tremblade, France, ${ }^{4}$ Centre Ifremer, Rue de \\ l'Ile d'Yeu, BP 21105, 44311 Nantes Cedex 03, France
}

\begin{abstract}
The history of French oyster culture consists of a succession of developmental phases using different species, followed by collapses caused by diseases. The indigenous species Ostrea edulis was replaced first with Crassostrea angulata, then $C$. gigas. France is now the top producer and consumer of oysters in Europe, producing around 120,000 t of the cupped oyster $C$. gigas annually, and an additional $1500 \mathrm{t}$ of the flat oyster $O$. edulis. Cupped oysters are produced all along the French coast from natural and hatchery spat. Various structures are used to collect spat from the wild. After a growing-on period, oysters are cultivated by three main methods: (1) on-bottom culture in the intertidal zone or in deep water, (2) off-bottom culture in plastic mesh bags in the intertidal zone, or (3) suspended culture on ropes in the open sea. The main recent development is the increasing use of hatchery oyster spat, especially triploids. Almost all oyster production is sold fresh and eaten raw straight from the shell. There is marked seasonality in sales, with the majority being made during Christmas and New Year. Abundant production and the lack of market organization induce strong competition among the production areas, causing prices to fall. Oyster farmers have developed strategies of sales promotion and regional quality labeling to overcome this difficulty. There are numerous production hazards, including environmental crises (microbiological pollution), unexplained mortality, and overstocking, and recent problems with toxic algae have disrupted oyster sales. However, oyster culture has many assets, including a coastal environment offering favorable sites for mollusc growth and reproduction. Oysters have been consumed in France since ancient times, and their culture is now well established with a concession system that favors small family firms. There is a young, well-educated farmer population, with technical expertise and savoir faire. Careful seawater quality monitoring ensures good consumer protection, and research is making innovative contributions (selection and polyploids). These points and opportunities for market expansion should bolster this industry's future, although the problem of toxic algae, probably linked to global warming and anthropogenic factors, and the threat of new diseases, pose vital questions for future research.
\end{abstract}

KEY WORDS: aquaculture, French production, Crassostrea gigas, Ostrea edulis, flat oyster, cupped oyster

\section{INTRODUCTION}

The 5500-km-long French coastline provides favorable environments for mollusc development, particularly oysters, which have always been much appreciated by the French. The north coast on the English Channel and the west coast on the Atlantic Ocean are subject to tidal effects, with mean tidal ranges varying from $10 \mathrm{~m}$ in the north to $4 \mathrm{~m}$ in the south. Water temperature fluctuates from $6-17^{\circ} \mathrm{C}$ in the north, but can reach more than $20^{\circ} \mathrm{C}$ in the Atlantic; salinity fluctuates from $20 \mathrm{~g} / \mathrm{L}$ in winter to $30-35 \mathrm{~g} / \mathrm{L}$ in summer. These conditions, in addition to a great diversity of coast types with numerous highly rich estuaries, favored the development of natural beds and rearing areas. Although conditions are quite different on the Mediterranean coast (lagoons with almost no tide, higher salinity [30-40 $\mathrm{g} / \mathrm{L}$ ], and warmer water in summer [up to $27^{\circ} \mathrm{C}$ ]), there are sites that are suited to oyster farming because of very high phytoplankton productivity. Oyster culture began in the mid-19th century and has remained traditional in France, the leading producer in Europe (Goulletquer \& Héral 1997).

History of Oyster Production: European Flat Oyster Ostrea edulis and Cupped Oysters Crassostrea angulata and Crassostrea gigas

The history of French oyster culture is complex. Production recently stabilized at a high level (Fig. 1), which is atypical, because production has been highly variable during the past century (Héral 1989, Goulletquer \& Héral 1997). In two

*Corresponding author: E-mail: pgoullet@ifremer.fr $\dagger$ This paper was presented at the $1^{\text {st }}$ International Oyster Symposium, Tokyo, Japan, July 13-14, 2005. periods, culture developed around a single species, followed by a population collapse and reconstruction of the industry based on a different species.

The first species, harvested from time immemorial by dredging natural beds, was the native Ostrea edulis. Oyster beds have been overexploited since the 18th century, especially along the Atlantic coast, and despite a long series of restrictive regulations, landings became poor and irregular during the 19th century (Goulletquer \& Héral 1997).

Culture began during the 17 th century with the use of former evaporation ponds for salt production in the Marennes region (Grelon 1978). Juvenile oysters were fished and placed in ponds (claires), then left for 4 or $5 \mathrm{y}$ before sale; however, this activity was marginal. Oyster culture expanded after several innovations. Between 1853 and 1859, Coste and De Bon began collecting wild spat (Coste 1861), and in 1865 the introduction of limed tiles resulted in an abundant and regular spat supply. On-growing techniques were then set up using special trays (Marteil 1979). However, the major innovation was administrative, with the 1852 law to regulate the exploitation of public maritime areas so that land for oyster production was state leased to farmers. Later modified in 1983 and 1989, the law is still in force. Precise criteria for allocating concessions favored those already on the "maritime register" (a register of sailors set up by the 17th-century pioneer of government information management, Jean-Baptiste Colbert) encouraged small family businesses and limited the authorized leased area.

Flat oyster culture was well developed at the turn of the 19th century, especially in the Bay of Arcachon, reaching 15-20,000 t (metric tons) per year between 1908 and 1912 (Bouchet et al. 1997). However, a crisis hit oyster populations throughout 


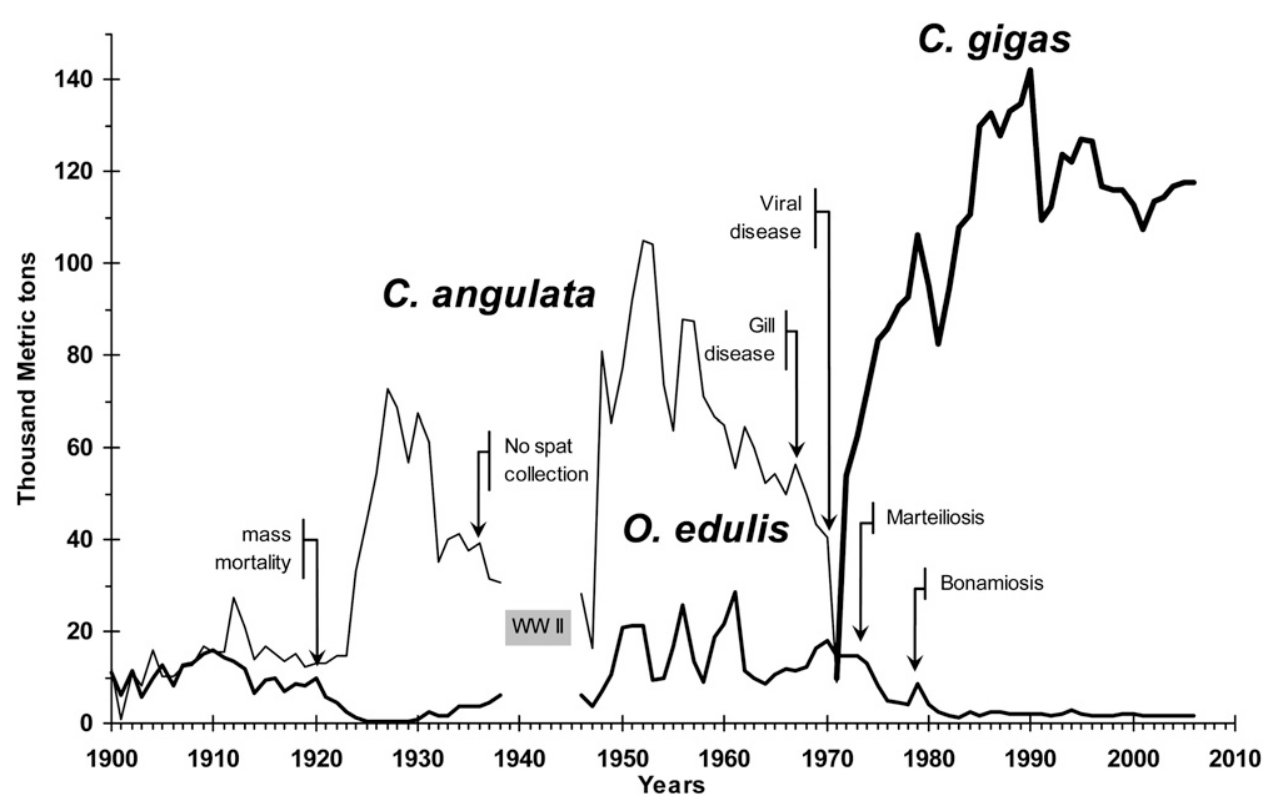

Figure 1. Historical trends of French oyster production (adapted from Héral 1989).

Europe after 1920, when massive, unexplained mortalities were reported. The species then disappeared from the Arcachon and Marennes regions. However, spat capture picked up again some time later in southern Brittany, where production has continued, reaching a maximum of 28,000 $\mathrm{t}$ in 1960 . The Mediterranean also produced flat oysters until 1950, when high mortalities occurred there as well, putting an end to production (Fauvel 1985). In Brittany, a disease caused by the protozoan Marteilia refringens broke out in 1968, followed by another disease in 1979 caused by the exotic parasite Bonamia ostreae. Production dropped from $20,000 \mathrm{t}$ to $2,000 \mathrm{t}$ and remains very low despite numerous efforts to assist its recovery.

The first imports of the Portuguese cupped oyster Crassostrea angulata into Arcachon date from 1860 and were made to compensate for the scarcity of flat oysters. The species then colonized the Atlantic coastline and both species, O. edulis and $C$. angulata, were produced concomitantly. The Portuguese cupped oyster replaced the endemic species in the main culture sites after the 1920 mortalities. Production increased rapidly and extended widely after World War II, reaching 90,000 t after 1950. Subsequently, oyster growth and survival began to decrease, indicating overstocking of production units (Héral 1989). Production gradually decreased until the "gill disease" outbreak in 1966 (Comps \& Duthoit 1976), later identified as a viral disease caused by an iridovirus (Comps et al. 1976). This disease spread throughout all culture zones, causing massive mortalities between 1970 and 1973, and leading to the total extinction of C. angulata in France. A limited population still exists in southern Portugal.

The oyster industry reacted quickly to this crisis with the "Resur" plan, which consisted of massive introductions of a new species, C. gigas, from the Pacific. After some small-scale trials (1966-1970), several hundred tonnes of C. gigas were imported from Canada between 1971 and 1973 to form brood stock in sanctuaries (Grizel \& Héral 1991). The species became established and an abundant spat settlement in Marennes-Oleron allowed healthy, fast-growing oysters to be produced. Meanwhile, 10,000 t spat were imported from Japan, and production increased quickly. Spat capture developed rapidly in Arcachon and Marennes, so that further spat imports became unnecessary.

Hence, despite several crises, France has always produced large quantities of oysters, unlike other countries such as England, where production plummeted after World War II (Neild 1995). The French market demand has always been high, particularly because of a longstanding tradition of eating oysters at Christmas and New Year.

\section{PRESENT STATUS OF CULTURE OF CRASSOSTREA GIGAS}

\section{Production Techniques}

The diversity of rearing areas gave rise to several techniques: on-bottom culture, off-bottom culture, and suspended culture. On-bottom culture consists of sowing oysters directly onto the intertidal seabed (about $25 \%$ of the total production) or in deep water, 5-15 m depth (10\%). Off-bottom culture is done by using plastic mesh bags set on trestles in the intertidal zone. This is now the principal technique used, accounting for $60 \%$ of the total production. Suspended culture $(5 \%)$ is done by hanging oysters fixed on ropes or in baskets from special frames in the Mediterranean lagoons or on lines in the open sea. Moreover, a great variety of culture practices exist as a result of several factors, including business size, location, labor force, and plurality of activity. All these methods, except deepwater culture, are considered to be labor intensive.

\section{Total Production}

Oyster production statistics, which are often imprecise, come from various sources: Ministry of Fisheries (DPMA), producer organizations (CNC: National Mollusc Production Committee), Ifremer, and OFIMER (National Bureau for Sea and Aquaculture Products). These statistics are summarized annually by Ifremer (Kalaydjan et al. 2004) (Fig. 2). The most recent 


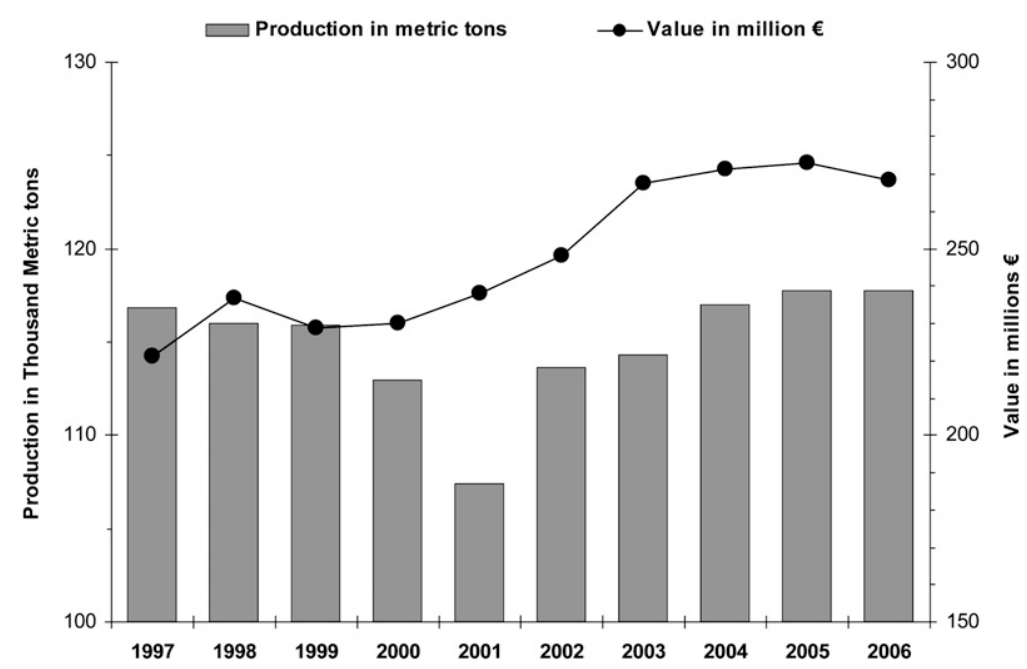

Figure 2. French annual production of the Pacific cupped oyster Crassostrea gigas. Reprinted with permission from Kalaydjan et al. (2004) and OFIMER (2008).

significant change occurred by the end of the 1980s, when, after a period of overstocking, oyster yield decreased, followed by a phase of industry restructuring. Several companies left the industry or merged, and total area of leased grounds concomitantly decreased, as did oyster stocking density. New European norms also affected several packing houses. Since then, oyster landings have been relatively stable, with an annual production of about 120,000 t of C. gigas oysters. Overall, French shellfish culture (oysters, mussels, and other species) produces 187,000 t, providing approximately 10,000 jobs in 3750 companies operating on a total lease area of 20,000 ha. Cupped oysters are therefore the principal shellfish production activity with 2650 companies operating on 14,000 ha.

A general census of oyster culture made by the Ministry of Agriculture gave a total of $107,400 \mathrm{t}$ for marketed oysters (Girard et al. 2005), however, this figure may underestimate production. The decrease in 2001 (Fig. 2) can be explained by several events: spat settlement was abnormally low in 1998; a major hurricane (1999) in the Marennes-Oléron region destroyed intertidal culture, including more than 20,000 t midsize oysters and wiped out oyster spat; and high mortalities occurred in Normandy.

France is the largest producer and consumer of oysters in Europe, and total production value has stabilized at about $€ 270$ million per annum, irrespective of the magnitude of production, suggesting a trend toward market saturation. A maximum of 152,000 $\mathrm{t}$ was reached in 1995 and 1996, together with the first difficulties with sales. Although difficult to estimate because of the open European market, 150,000 t appears to be the upper threshold.

\section{Main Characteristics of Production Zones}

Seven production regions with different characteristics can be distinguished (Fig. 3). Production data in the following paragraphs are for 2001 unless stated.

\section{Normandy}

The exploitation of this production zone since the 1960s has relied on the mesh bag production technique in vast intertidal areas. Bottom culture is not possible there because of wave movement. Oyster culture has replaced traditional mussel production in several areas. About 20,000 t cupped oysters are produced over 1025 ha (168 businesses). Good growth is achieved and half the oysters from Normandy are later transferred to Marennes-Oléron to be refined in oyster ponds (or claires). Normandy is more a region of production than of trade. Recently, large mortalities affected the Baie des Veys (loss of $2000 \mathrm{t}$ in the year 2000), probably because of environmental anomalies (Ropert \& Kopp 2000).

\section{Brittany}

The Brittany coastline is highly varied with numerous favorable bays and estuaries, and it has a longstanding tradition of flat oyster culture. Oysters are cultivated in mesh bags $(70 \%)$ or in deep waters. Main sites are Cancale, Paimpol, and Morlaix in the north, and the Gulf of Morbihan and the Bay of Quiberon in the south. Numerous secondary sites such as the Belon River are also exploited. Many farmers from Vendée or Charente-Maritime focus on oyster growth, then transfer stocks south for refining. Total production was estimated at 21,500 t over 4500 ha (490 businesses). In the Bay of Quiberon, deepwater culture has dramatically increased, with 100 farms producing about 10,000 t per year from more than 2600 ha of concessions (Mazurié et al. 2002).

\section{Vendée}

Farming began in Bourgneuf Bay in 1947 with oysters cultured directly on collector tubes and in mesh bags. The 2001 production was around 8600 t from about 1070 ha (290 businesses). Yields are usually low mainly as a result of poor culture practices, such as overloading these containers, which limit growth and meat quality. Half the oysters produced are refined in local oyster ponds. As a result of the presence of polders (low-lying land enclosed by embankments) and suitable quality underground seawater, this is now the leading region for hatchery and nursery production.

\section{Charente-Maritime (Ile de Ré and Marennes-Oléron)}

Marennes-Oléron Bay is a renowned site for oyster culture, with a longstanding tradition reaching back to the transformation 


\section{NORTH BRITTANY}

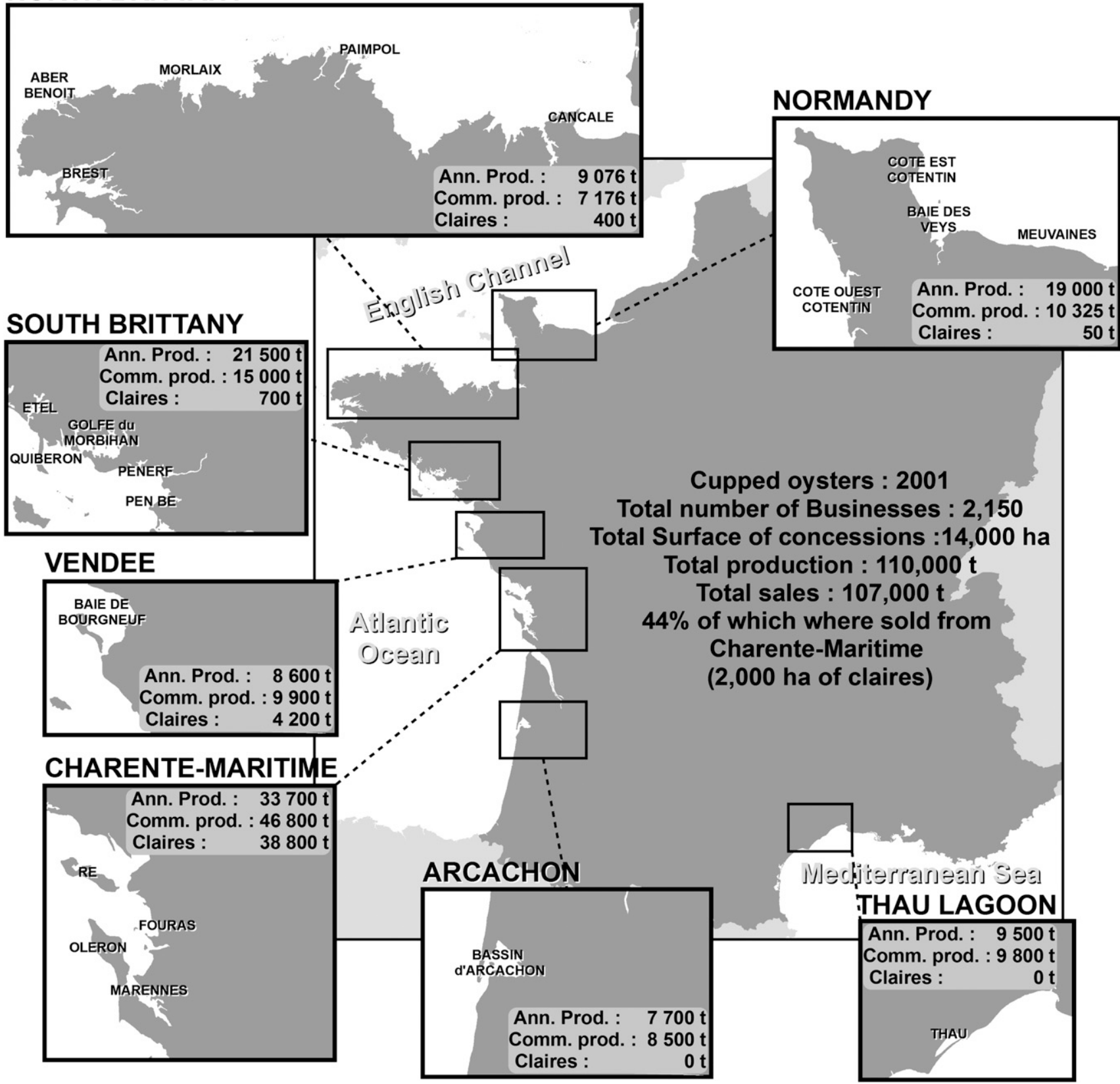

Figure 3. Main characteristics of French oyster rearing areas (data from the 2001 National Census, Girard et al. 2005). All figures are in metric tonnes. Ann. Prod., annual production; Claires, oysters refined in oyster ponds (claires); Comm. Prod., commercialized production (amount marketed).

of ancient salt works in the 17th century (Grelon 1978). It is the main area of spat collection, with about 3 billion spat out of the total 4.5 billion (2001), and it sustains all the other regions by supplying spat. It is mostly collected on corrugated PVC tubes and dishes. Production is characterized by diverse farming practices, overstocking of cultivated beds, and generally high production costs for both Marennes-Oléron and Ile de Ré rearing areas. Production comes from 4400 ha, including 2100 ha of claires (1084 businesses). One of the handicaps to production is the silting up of growing areas (parcs), meaning that boating distances to the concessions are increased and that working time is tide limited. Production costs are therefore higher than elsewhere. Moreover, mussel spat settlement is avoided by late oyster deployment in the growing season, therefore limiting overall oyster annual growth. The resulting numerous stock rotations for the different culture phases increase costs still more. Many farmers have leasing grounds in other production zones to optimize rearing cycles. Other farmers purchase oysters, particularly from areas that produce fleshy oysters such as Normandy and Brittany, and then refine them in claires. This practice, which earns the well-known Marennes-Oleron labels (fines de claires, spéciales de claires), increases product value. This area markets about $46,800 \mathrm{t}$ of oysters per year (commercialized production) and grows only 33,700 t (annual total production, Fig. 3).

Overcrowding and associated poor growth have required new management practices in Marennes-Oléron Bay to upgrade 
leasing grounds and to limit wild colonization from oyster spat and trophic competitors (Goulletquer \& Héral 1997).

\section{Arcachon}

Oyster culture in the Arcachon Basin has an ancient, rich, and turbulent history characterized by several upheavals, from the beginning of the 1860 s to the present, arising from overproduction, environmental degradation, and overstocking (Bouchet et al. 1997). Arcachon produced $7800 \mathrm{t}$ cupped oysters and about 0.5 billion spat ( 374 businesses), with the latter figure considered abnormally low spat production for this highly specialized area.

The most recent crisis involved oyster contamination with toxic harmful algal blooms (HAB), which meant that oyster sales were prohibited for several weeks during the 2005-2006 summer. Uncertainties resulting from $\mathrm{HAB}$ are of major concern, especially because the cause was not known. Economic destabilization of oyster farming in Arcachon had previously occurred as a result of the effect of tributyltin (TBT)-based antifouling paint used for sailboats (Alzieu et al. 1989). This product lowers oyster quality by deforming the shells (muddy blisters) and by impeding growth. It also had a very detrimental influence on reproduction, leading to a lack of spat collection for 5 y (1977-1981). This crisis deeply affected the oyster industry and drastically reduced the number of businesses. Production is now about 8000 t using mesh bag culture.

\section{Mediterranean: Thau, Leucate, and Corsica}

With annual oyster production of 9500 t from more than 360 ha (248 businesses), the Thau Lagoon is the major site for Mediterranean production; other important locations include Leucate Lagoon $(600 \mathrm{t})$ and Corsica (200 t). The farming technique used is specific to the Mediterranean, where there is no tide. Oysters are cultured on ropes, hanging from permanent structures known as tables that are driven into the sediment. Thau Lagoon productivity is very high and growth is extremely fast (12-18 mo to reach commercial size).

Without natural spat settlement, oysters are brought in from the Atlantic coast or from hatcheries. Recently, a new technique ("pearl net") for on-growing small hatchery spat was successfully tested. Because this spat yields excellent-quality product, its use is increasing rapidly in Thau. Furthermore, hatcheries can produce triploid oysters, with a quality that is better in summer during the tourist season. Abnormal mortality rates and HABs have recently affected production in Thau and Leucate lagoons, respectively.

\section{End Product: Improving Quality of Cupped Oysters}

\section{Market Context}

Virtually all French oysters produced are sold fresh, mostly eaten raw straight from the shell. Annual production corresponds to the French market demand because exports are relatively minor $(5 \%)$. Oysters are considered a traditional, affordable luxury product.

There is strong sales seasonality, with more than half the consumption taking place during Christmas and New Year. At that time, strong competition occurs between oysters and other products with a similar "festive" image (e.g., salmon and foie gras). Producers are now finding it difficult to cover production costs, which are increasing more quickly than sales prices. Sales to the wholesale market are decreasing in favor of more profitable direct sales (about 30\%). The market is not well organized, and the different production zones compete with each other, thus bringing the price down. Wholesale prices are highly variable (an average of $€ 2.3 / \mathrm{kg}$; Fig. 2) (Kalaydjan et al. 2004; OFIMER 2008). Despite a strong emphasis on improving the labeling strategy, producer organizations still cannot maintain prices.

Oysters still have a very good image with consumers. However, apart from health concerns, there is increasing demand for product information including origin, culture site, quality, and sustainability. Efforts to promote oysters and improve their quality are carried out through both norms (sizes, conditioning, and filling index) and product identification (designations, certifications, and labels).

\section{Quality Criteria for Cupped Oysters}

Oysters must have an appropriate shape; they should never be too long and narrow, but should be well cupped. The outside of the shell should be smooth without barnacles or worm tubes. The inner surface should be clean, have hard nacre, and be free of blisters or chambers caused by spionid polychaetes or the influence of antifouling TBT paints. Short heating (boiling) is now commonly used to remove any fouling organisms from the shell.

The sensory attributes of the soft tissue are also important because the flesh should fill out the shell and have a slight, pleasant iodine smell. A black lacelike mantle is another good feature. Oyster meat should be firm, not milky (i.e., be without gametes), be ivory in color, not too salty, and "taste of the sea" (Neild 1995). Because each site confers its own particular taste to the flesh, oysters are regarded as local products. Although the taste is highly variable, smoothness and a slightly sweet flavor are generally appreciated. A short storage phase in filtered seawater facilitates remove any particles from the pallial cavity.

Besides the compulsory sanitary controls (EU DirectivesHygiene package), oyster quality in the main basins is regularly tested within the framework set up by Ifremer to monitor oyster growth (Fleury et al. 2001).

\section{Oyster Refining in Oyster Ponds (Claires)}

Refining is an operation intended to improve product quality (closure strength, meat content, and better taste) and commercial value. Claires are small, shallow, earth-bottomed ponds communicating with the sea. Abundant phytoplankton blooms fatten oysters cultured there at low density, giving them an especially desirable taste. The occasional presence of a particular microalgae species, Haslea ostrearia (diatom), gives the gills a green color and the oysters a high market value. According to the duration of immersion, culture density, and fattening index (percent flesh), oysters are classified as fines de claires, spéciales de claires (Grelon 1978, CNC 2001), or the top-quality level, pousse en claire, meaning their growth occurs in those ponds.

\section{Oyster Classification According to Weight and Soft Tissue (Filling Rate)}

The most basic information for consumers consists of a national system of oyster classification based upon total individual weight. This is compulsory for all oysters whether they are sold by the kilo (most frequent) or by the dozen. Oysters are graded from 0 (very large) to 5 (very small), according to their unopened weight. Consumers do not like oysters that are too 
big or too small and the most frequently consumed grade is 3 (66-85 g).

A second criterion for oyster classification is the filling rate, calculated as a soft tissue percentage. Oysters are not classified if the index value is less than 6.5 , and they are called fines and spéciales when the index is between 6.5 and 10.5, and more than 10.5, respectively (CNC 2001). Classes fines de claires and spéciales de claires refer only to oysters that have been refined in saltwater ponds.

\section{Efforts to Promote and Publicize Products}

In addition to national advertising campaigns, each region promotes and advertises its products. Many different criteria are used for labeling oysters with these objectives in mind:

Promotion of products: generic brands such as the Belon $(O$. edulis) or geographical brands such as oysters from MarennesOléron, Bouzigues, Arcachon, Normandy, or Brittany

Product specificity: classification according to the filling rate, duration in saltwater ponds (refined), and local-level geographical origin, such as Indication Géographique Protégée (or IGP, a European Union label) and Appellation d'Origine Contrôlée (or AOC, granted by the French Ministry of Agriculture)

Quality brands: red label "Marennes-Oléron," "Pousse en Claires" (refined in saltwater ponds with precise oyster quality specifications), certificate of production conformity (CCP) "Exquise de la Méditerranée" (defining a precise process), names of noncertified individuals referring to particular producers (e.g., special Papin or Gillardeau)

These efforts have been problematic, with the plethora of competing regional and local designations confusing consumers. There is also significant product variability depending on environmental conditions; achieving consistent quality is challenging. Therefore, most labels focus on managing processes rather than oyster specifications. Beyond measurable norms (size and filling index), the multiple quality criteria are difficult for consumers to understand because they may lack knowledge of product quality, which in turn may not be reflected in the sale price.

\section{Product Diversification: Polyploidy}

A polyploid is an organism with more than 2 base genomes. Triploid oysters, with 3 base genomes corresponding to 30 chromosomes per cell, are now commonly produced in hatcheries. Triploidy essentially induces 2 advantages in the cupped oyster: a quicker growth rate and near sterility, endowing the animal with a more consistent quality (filling rate) (Goulletquer et al. 1996, Gagnaire et al. 2006). Triploid oyster production is increasing (20-30\% of the total production), and $80 \%$ of the 800 million spat sold by hatcheries in 2005 were triploids. Demand for hatchery spat is very strong despite its higher price, because it is perceived to be superior.

\section{Current issues for French oyster production}

Oyster production faces numerous constraints: Biological Constraints

- Disease: an inherent risk in monoculture

- Basin management: exceeding trophic capacity, summer mortality, and limited freshwater inputs resulting from poor watershed management
- Spat recruitment: unreliable

Environmental Constraints

- Pollution: bacteria and chemical contaminants

- Toxic algae: diarrhetic shellfish poisoning (DSP), paralytic shellfish poisoning (PSP), and amnesic shellfish poisoning (ASP)

- Competition for space

Socioeconomic Constraints

- Business upgrading to meet European norms

- Market organization

The history of French oyster production is based on monoculture, which involves risks that necessitate research into mollusc pathology and genetics.

In pathology, the primary emphasis is on prevention by monitoring mollusc resources, testing imports, identifying pathogens, and developing diagnostic tools. These include the REPAMO network (Réseau de Pathologie des Mollusques) objectives, set up by the Ifremer laboratory at La Tremblade, which is also the European reference laboratory for mollusc pathology and for the International Animal Health Organisation (Thébault et al. 2000). These preventive measures are complemented by research on the major diseases, based on the following objectives: identifying pathogens, discerning virulence factors, establishing experimental protocols for disease testing, developing diagnostic tools, understanding developmental cycles, and studying the effects of diseases as well as their evolution in space and time.

Current genetics research consists of: (1) characterizing the domestic and wild populations to be farmed; (2) evaluating new species, brood stock from new populations, and hybrids to limit monoculture risks; (3) selecting disease-resistant or -tolerant strains to address production decreases; and (4) improving breeding lines (growth performance, flesh quality, or survival) to increase productivity and limit summer mortality syndrome (Degrémont et al. 2007).

Several basin management studies have modeled how ecosystems function in mollusc production zones, particularly in Marennes-Oléron, where there is chronic overstocking. Efforts are underway to decrease local biomass in the intertidal zone. Offshore culture might compensate for this decrease by using deepwater culture on the bottom or on ropes attached to long lines. These projects have led to conflict, mainly with fishermen and other sea users (e.g., tourism, navigation). Moreover, research has focused on the coupling between watershed and coastal areas. One of the remaining major issues is freshwater management, which is exacerbated by droughts and increasing impacts of global changes $\left(1.5^{\circ} \mathrm{C}\right.$ seawater temperature increase during the past $25 \mathrm{y}$ ), especially because freshwater runoff is critical for primary productivity. Another focus is understanding abnormal spat recruitment; most of the most abnormal years (huge or very low recruitment) were reported during the past $10 \mathrm{y}$, probably because of global climate change.

For several years, oyster culture has also been facing summer mortality problems, sometimes of catastrophic proportions. In response, a comprehensive 4-y multidisciplinary research program (MOREST) was undertaken to combine research on physiology, ecophysiology, pathology, and genetics, and to focus on interactions. Water temperatures more than $19^{\circ} \mathrm{C}$ appear to be a trigger to mortality, but many other factors are 
also involved: genetic origin; reproduction in relation to food availability; pathogens including Vibrio spp., herpesvirus OHSV-1; water inflow from rivers and catchments; and sediment characteristics. A critical result was the potential for reducing summer mortality by using resistant $C$. gigas strains, thereby opening the way for a massive selection program (Samain \& McCombie 2008).

A major effort has been made during the past $10 \mathrm{y}$ to enforce the precise requirements of European sanitary rules. Culture areas are classified according to the density of fecal bacteria in the water, and farmers have developed their own monitoring systems. Research is underway to complete regulations that also take into account viral concentrations to ensure better consumer protection.

Environmental constraints stemming from the quality of farmed waters are also closely monitored by Ifremer through different monitoring networks on (1) microbiological quality of oysters (REMI); (2) toxic phytoplankton blooms (DSP, PSP, ASP) (REPHY), and (3) chemical contaminants (RNO). Wherever there is a strong increase in toxic algal blooms, emphasis is placed on improving monitoring and understanding such phenomena. Shellfish detoxification trials are also underway in an attempt to restrict their economic impacts (Lassus 2002).

Registered as expéditeurs, $70 \%$ of companies have the authorization to sell on the wholesale network or as retailers. Oyster farmers have proved their dynamism by adapting their shipping units to European rules, and much has been done to modernize businesses during the past $10 \mathrm{y}$.

\section{CONCLUSION}

French mollusc production has many strong points, including numerous natural sites favorable for this industry. Oyster collection and farming are ancient activities that have overcome major crises, largely related to disease and spat supply, by moving to exotic species. Oyster farming is now well established along the coast, within a suitable leasing system. There is a young, well-educated farmer population, with technical expertise and savoir faire. Oyster consumption is traditional and festive, but could undoubtedly be increased by offering improved product information to the consumer and by improving year-round quality (e.g., for summer tourism). Current efforts to improve quality should help meet these goals.

Mollusc production also benefits from strong research support. Even though progress is slow, recent practical innovations are becoming important to the oyster industry, such as the use of triploid oysters and, in deepwater culture, long lines. Farms are monitored through microbiological and phytoplankton toxin testing, thus guaranteeing a healthy product for the consumer. An important new development has come from the increasing use of hatchery spat (about $30 \%$ of total supply). Hatchery production has sustained more reliable production cycles, via faster and more uniform growth as a result of improved expertise and by brood stock selection as well as other genetic progress (triploids now produced by crossing tetraploids and diploids). Despite initial concerns from producers about triploids, resulting from possible consumer acceptability problems, there is booming demand for triploid spat, because of its excellent performance during grow-out. Growth is faster, with sometimes a 3-y production cycle being reduced by $1 \mathrm{y}$. Mortality is also reduced, and taste and appearance are often better, particularly in the summer.
There are also numerous drawbacks. Oyster farming is a traditional and individualistic profession with strong competition among producers. Furthermore, businesses are often below the critical size for incorporating modern developments. Markets are very complex, and the lack of organization leads to excessive competition among production zones. A key issue is the lack of capacity to predict yearly landings and, hence, to adjust prices accordingly. Producer organizations have not managed to regulate the situation, and prices are typically low. As a consequence, small producers tend to sell their oysters directly to increase their value, but this is time-consuming and detrimental to production. Oyster consumption is very seasonal, but consumers do not necessarily differentiate on the basis of quality. Overstocking of farms is often chronic, and numerous natural hazards (climate, bacterial contamination, toxic algae, and mortality) increase production costs and market instability. Monoculture entails serious risks and the industry's history confirms the potential impact of a new disease.

Oyster culture in the near future is likely to experience the following major challenges:

Within the Profession

- Control the quantity and quality of production, and facilitate the shellfish diversification.

- Lower production costs by using new techniques (mechanization and selection) and production zones (long-line rope culture in deep water).

- Organize the market through price support, promotion, quality brand recognition, and extension of the marketing period (e.g., selling triploids during the summer).

- Maintain political and economical strengths against competing coastal users.

\section{Environmental Management}

- Monitor major hazards by detecting microbial and chemical pollution and toxic algae.

- Improve health quality by maintaining water quality in rearing areas and improving treatment procedures (purification and detoxification).

- Reduce risks of animal diseases by prophylaxis (prevention).

- Integrate coastal zone management to reduce spatial competition from tourism, fisheries and environmental protection through cooperation and regulation.

\section{Adapting to Global Changes}

Although a "revolution" has been achieved in shellfish treatment according to European rules, there has been comparatively little innovation in production techniques, which remain very traditional and labor intensive. In the current context of strong market competition, efforts to improve oyster quality are essential for the future. Quality certifications will require better biotechnological management and testing. Many small companies are not large enough in terms of manpower to carry out this quality control process. As in agriculture, business mergers will certainly be ongoing and new organizations (e.g., co-operatives) will be required to address new challenges cost-effectively. In offshore culture operations, the use of hatchery spat in association with long lines may permit some mechanization. Cost reduction should also be possible through progress with domestication - for example, by selected oysters for lower summer mortality. 
Apart from the risk of disease affecting C. gigas, the main problem is the increasing occurrence of toxic algae, which is probably related to global warming and anthropogenic factors. This is a key challenge for the near future that requires a capacity to manage detoxification processes. Nevertheless, the industry's dynamism and increasingly greater efforts in organi- zation and environmental management should allow the maintenance of French oyster production in the future.

\section{ACKNOWLEDGMENT}

The Foundation of Oyster Research Institute contributed to publication expenses.

\section{LITERATURE CITED}

Alzieu, C., M. Héral \& J. P. Dréno. 1989. Les peintures marines antisalissures et leur impact sur l'ostréiculture. Equinoxe 24:22-31.

Bouchet, J. M., J. P. Deltreil, F. Manaud, D. Maurer \& G. Trut. 1997. Etude intégrée du bassin d'Arcachon. Tome 5. Pêche et Ostréiculture. IFREMER Report (ed.), DEL 97.09/Arcachon. 128 pp.

CNC. 2001. Accord interprofessionnel de dénomination et classifications huîtres creuses. Comité National de la Conchyliculture, Paris. 9 pp.

Comps, M., J. R. Bonami, C. Vago \& A. Campillo. 1976. Une virose de l'huître portugaise Crassostrea angulata. C. R. Acad. Sci. Paris 282D:1991-1993.

Comps, M. \& J. L. Duthoit. 1976. Infection virale associée à la "maladie des branchies" de l'huître portugaise Crassostrea angulata. C. R. Acad. Sci. Paris 283D:1595-1597.

Coste, M. 1861. Voyage d'exploration sur le littoral de la France et de l'Italie. Paris: Imprimerie Impériale. 292 pp.

Degrémont, L., B. Ernande, E. Bédier \& P. Boudry. 2007. Summer mortality of hatchery-produced Pacific oyster spat (Crassostrea gigas). I. Estimation of genetic parameters for survival and growth. Aquaculture 262:41-53.

Fauvel, Y. 1985. L'étang de Thau: compétition dans l'exploitation, une redite. Rapport IFREMER/DRV/SDA. (Ifremer Nantes ed.), $48 \mathrm{pp}$.

Fleury, P. G., F. Cornette, S. Claude, H. Palvadeau, S. Robert, F. d'Amico, P. Le Gal \& C. Vercelli. 2001. Réseau de suivi de la croissance de l'huître creuse sur les côtes françaises (REMORA), résultats des stations nationales, année 2000. Rapport IFREMER, DRV/RA/RST/01-02. Ifremer La Trinité sur Mer ed., 48 pp.

Gagnaire, B., P. Soletchnik, P. Madec, P. Geairon, O. Le Moine \& T. Renault. 2006. Diploid and triploid Pacific oysters, Crassostrea gigas (Thunberg), reared at two heights above sediment in MarennesOleron Basin, France: Difference in mortality, sexual maturation and hemocyte parameters. Aquaculture 254:606-616.

Girard, S., J. A. Pérez Agundez, L. Miossec \& N. Czerwinski. 2005. Recensement de la conchyliculture. Agreste, Paris, ed. Cahier no. 1. $87 \mathrm{pp}$.

Goulletquer, P. \& M. Héral. 1997. Marine molluscan production trends in France: from Fisheries to aquaculture. U.S. Dep. Commerce. NOAA Tech. Rep. NMSF. 129:137-164.

Goulletquer, P., J. P. Joly, A. Gérard, E. Le Gagneur, J. Moriceau, J. M. Peignon, S. Heurtebise \& P. Phelipot. 1996. Performance of triploid
Pacific oysters Crassostrea gigas (Thunberg) reared in high carrying capacity ecosystem: survival, growth, and proximate biochemical composition. Haliotis 25:1-12.

Grelon, M. 1978. Saintonge. Pays des huîtres vertes. La Rochelle, France: Rupella ed., 364 pp.

Grizel, H. \& M. Héral. 1991. Introduction into France of the Japanese oyster (Crassostrea gigas). J. Cons. Explor. Mer. 47:399-403.

Héral, M. 1989. L'ostréiculture française traditionnelle. In: G. Barnabé, editor. Aquaculture. Paris: Lavoisier. pp. 347-397.

Kalaydjan, R., G. Bihet, F. Daurès, J. Dehez, S. Girard, O. Guyader, J. A. Pérez Agundez \& O. Thébaud. 2004. Données économiques et maritimes françaises 2003. Bilans et prospectives Ifremer. Ifremer ed., Plouzané. 95 pp.

Lassus, P. 2002. Coquillages contaminés par des phycotoxines paralysantes. Vers une procédure de détoxification. Série comportement des polluants. Ifremer ed., Plouzané. 48 pp.

Marteil, L. 1979. La conchyliculture Française. Troisième partie. L'ostréiculture et la mytiliculture. Rev. Trav. Inst. Pêches Marit. 3 vol. ISTPM ed., Nantes. 452 pp.

Mazurié, J., M. Foucart, A. Langlade, J. F. Bouget, P. G. Fleury, J. P. Joly \& A. G. Martin. 2002. Analyse des pratiques, contraintes et performances d'élevage de l'huître creuse Crassostrea gigas, en 2001, sur différentes concessions en eau profonde de la Baie de Quiberon. Rapport IFREMER, DRV/RA/RST. 2002-08. Ifremer La Trinité sur Mer, ed., 62 pp.

Neild, R. 1995. The English, the French and the OYSTER. London: Quiller Press. 212 pp.

OFIMER. 2008. Key figures for the fisheries and aquaculture sector in France. 36 pp. Retrieved September 2008, from www.ofimer.fr/ PDF/obsec/Chiffres_cles_2008.ang.pdf.

Ropert, M. \& J. Kopp. 2000. Etude des mortalités ostréicoles de l'hiver 1998/1999 en Baie des Veys. Rapport IFREMER, DRV/RA/RST/ 2000-10. Ifremer Port en Bessin ed., 52 pp.

Samain, J. F. \& H. McCombie, editors. 2008. Summer mortality of Pacific oyster Crassostrea gigas. The MOREST project. QUAE ed., Versailles. 400 pp.

Thébault, A., M. Robert, B. Chollet, M. Dumais, J. P. Joly, C. Garcia, T. Comtet, M. J. Le Coguic, A. G. Martin \& Y. Pichot. 2000. Bilan 2000 du réseau REPAMO. Réseau National de surveillance zoosanitaire des mollusques marins. Rapport IFREMER, DRV/RA/ LPG. Ifremer La Tremblade ed. 79 pp. 